DOI: https://doi.org/10.18371/fp.4(36).2019.190233

УДК 378.01:330.1

\title{
СИНЕРГЕТИЧНИЙ ПІДХІД ДО ЗВІТНОСТІ В УКРАЇНІ
}

\author{
ЛЮТОВА Ганна Михайлівна \\ к.е.н., доиент \\ Черкаського навчально-наукового інституту \\ ДВНЗ «Університет банківської справи» \\ e-mail: lutova.anna.m@gmail.com
}

ТУПИЦЬКА Анастасія Валентинівна

студентка

Черкаського навчально-наукового інституту

ДВНЗ «Університет банківської справи»

e-mail:anastasia.tupitskaya@gmail.com

\begin{abstract}
Анотація. У статті розглянуто основні етапи розвитку бухгалтерської звітності, виявлено недоліки фінансової звітності, щзо зумовили виникнення концепції нефінансової звітності. Визначено сутність концепиіі сталого розвитку та сочіальної відповідальності бізнесу. Розглянуто підходи вчених до визначення сутності нефінансової звітності, встановлено ї̈ користувачів та їх інформаційні потреби. Досліджено передумови виникнення конщепиії інтегрованої звітносmi. Проведено SWOT-аналіз фінансової, нефінансової та інтегрованої звітності та виявлено синергетичний ефект від поєднання фінансової та нефінансової інформації в інтегрованому звіті.
\end{abstract}

Ключові слова: інтегрована звітність, нефінансова звітність, фінансова звітність, сталий розвиток, стратегія, ризики, синергія.

Постановка проблеми. В умовах інтеграції до світового співтовариства, зокрема до Європейського Союзу, відбувається зміна поглядів на склад i
Аннотация. $B$ cmaтье рассмотрены основные этапы развития бухгалтерской отчетности, выявлены недостатки финансовой отчетности, обусловивщие возникновение концепции нефинансовой отчетности. Определена сущность концепциии устойчивого развития и сочииальной ответственности бизнеса. Рассмотрены подходы ученых $к$ определению сущности нефинансовой отчетности, установлено пользователей и их информационные потребности. Исследовано предпосылки возникновения концеепии интегрированной отчетности. Проведен SWOTанализ финансовой, нефинансовой и интегрированной отчетности и выявлен синергетический эффект от сочетания финансовой и нефинансовой информаџии в интегрированном отчете.

Ключевые слова: интегрированная отчетность, нефинансовая отчетность, финансовая отчетность, устойчивое развитие, стратегия, риски, синергия.

структуру фінансової звітності, яка ще донедавна вважалася основним джерелом інформації для прийняття рішень. Зміни, що відбуваються в суспі- 
льстві та впливають на підприємницьку діяльність, призвели до того, що інформації, що наводиться у фінансовій звітності чи окремих нефінансових звітах, вже виявляється недостатньо для зацікавлених користувачів. Окреме оприлюднення фінансової та нефінансової звітності не дає можливості розкрити взаємозв'язки між фінансовими та нефінансовими показниками, стратегією підприємства, ризиками та корпоративним управлінням. Таку інформацію може надати інтегрована звітність, синергетичний підхід до формування якої дасть можливість формувати інформацію для стратегічного розвитку підприємства у всіх його аспектах: економічному, соціальному, екологічному.

Аналіз останніх джерел та публікацій. Дослідженню сутності інтегрованої звітності, 3 метою виявлення іiі особливостей, проблем та переваг формування, присвячено праці таких зарубіжних та вітчизняних дослідників: М. В. Корягіна, П. О. Куцика, Г. І. Ляховича, К. В. Безверхого, А.М. Гордієнко, С. Король, Т.І. Хомуляка, Р.Дж. Екклза, М.А. Проданчук, Н.Н. Балашової, Н.Ю. Сршової, Р.О. Костирко, Р.В. Кузіної, Н.О. Лоханової, А.С. Николишина та ін.

Цілі статті. Визначити особливості фінансової та нефінансової звітності, а також виявити синергетичний ефект від поєднання фінансових та нефінансових показників в інтегрованому звіTi.

Виклад основного матеріалу. Бухгалтерська звітність, як засіб взаємодії між зацікавленими користувачами облікової інформації та суб'єктами, відповідальними за іiі надання, постійно розвивається задля підвищення ефективності такої взаємодії. Зважаючи на це, головною причиною еволюції звітності можна вважати невідповідність інформації, що подається у такій звітності, реальним потребам стейкхолдерів, зокрема інвесторів. Економічні, екологічні та соціальні чинники змінили потреби користувачів інформаціï, зробивши актуальним питання використання підприємством різних видів капіталу (інтелектуального, людського, інноваційного) та впливу цього використання на здатність підприємства створювати вартість впродовж тривалого періоду.

Так, науковці М.В. Корягін та П.О. Куцик [1, с. 141] розкрили парадигмальний генезис бухгалтерської звітності, що надає можливість пояснити сучасний етап іiі історичного розвитку. На їх думку, він складається 3 наступних парадигм: бухгалтерські звіти; фінансова звітність; фінансова та управлінська звітність; фінансова звітність, нефінансова звітність та управлінська звітність; інтегрована звітність та управлінська звітність.

Г.І. Ляхович та М.Я. Заяць у розвитку бухгалтерської звітності виділяють чотири основні етапи еволюції: 1) критика концепції фінансової звітності; 2) формування додаткових звітів; 3) виникнення концепції нефінансової звітності; 4) виникнення концепції інтегрованої звітності [2, с. 142-144].

Як відомо, фінансова звітність містить інформацію про фінансовий стан, результати діяльності, а також про рух грошових коштів підприємства за певний період. Наприкінці 20 століття інформації, що наводилась в фінансовій звітності, виявилось недостатньо 
для зацікавлених користувачів [2, с. 142-143]. Саме неврахування всіх суттєвих аспектів діяльності підприємства стало однією 3 причин критики концепції фінансової звітності. В зв'язку з цим виникла велика кількість пропозицій щодо розширення іiі складу. Важливим чинником стало також погіршення екологічної ситуації в світі, спричинене антропогенним впливом, що посилило необхідність висвітлювати інформацію щодо впливу діяльності підприємства на навколишнє середовище.

Враховуючи причини, що зумовили критику існуючої концепції, для усунення проблем відповідності фінансової звітності потребам зацікавлених сторін, поступово почали виникати спроби створення окремих спеціалізованих звітів, які б містили інформацію щодо певних сторін діяльності підприємства (соціальні звіти, екологічні звіти тощо). Це спричинило появу нової моделі звітування, що включала фінансову звітність, яка формувалась на основі чітких регуляторних вимог, та спеціалізовані звіти, що задовольняли додаткові потреби користувачів.

3 часом стало зрозуміло, що інформація із спеціалізованих звітів частково повторює інформацію, наведену у фінансовій звітності або примітках до неї, тому розпочався пошук підходів для формування загальної концепції побудови спеціалізованих звітів. Пізніше було прийнято рішення про використання нової моделі звітування, а саме: у фінансовій звітності та примітках до неї відображати фінансові показники, а в нефінансовій - всі інші аспекти діяльності. Так виникла концепція нефінансової звітності.
Нефінасова звітність $є$ інструментом для відображення результатів діяльності підприємства стосовно соціальної відповідальності бізнесу, яка, в свою чергу, пов'язана 3 концепцією сталого розвитку.

Сталий розвиток - загальна концепція, яка обгрунтовує необхідність встановлення балансу між задоволенням теперішніх потреб суспільства та захистом інтересів майбутніх поколінь, стосовно їх потреби в безпечному і здоровому довкіллі. Як визначають дослідники [3, с. 352], концепція сталого розвитку сформувалась в результаті об'єднання трьох основних складових: економічної (оптимальне використання обмежених ресурсів i використання екологічних технологій), соціальної (орієнтація на людину і спрямування на збереження стабільності соціальних і культурних систем) та екологічної (забезпечення цілісності біологічних i фізичних природних систем).

Соціальна відповідальність бізнесу стосується таких аспектів: дотримання прав людини, вимог законодавства; захист навколишнього природного середовища; ділова та корпоративна етика, дотримання міжнародних норм поведінки; співпраця із зацікавленими сторонами, а також прозорість та підзвітність.

Так, К.В. Комарова та Н.В. Ковальчук [4, с. 26] виділяють три рівні для визначення соціальної відповідальносTi:

1. Базовий рівень - бізнес платить податки у повному обсязі.

2. Корпоративний рівень - соціально відповідальний бізнес повинен пла- 
тити економічно обгрунтовану зарплату.

3. Вищий рівень - соціально відповідальний бізнес на добровільній основі займається добродійністю.

Таким чином, окрім покращення репутації підприємства, соціальна відповідальність також забезпечує конкурентну перевагу на довгострокову перспективу.

Варто зазначити, що науковці не виділяють загальної назви для звітів, що стосуються різних сторін соціальної відповідальності бізнесу, тому використовуються такі поняття як «соціальний звіт», «звіт із корпоративної соціальної відповідальності», «звіт із корпоративної відповідальності», «звіт зі сталого розвитку», «звіт із прогресу» тощо. Всі вони характеризуються спільною метою (надати інформацію про результати діяльності підприємства у соціальній, екологічній сферах); наявністю даних про якісні та кількісні аспекти такої діяльності; деякими відмінностями, що стосуються відображення різних сфер соціальної діяльності підприємств. Якщо об’єднувати всі ці звіти під єдиною назвою, доцільно буде обрати термін «нефінансова звітність», так як він відображає зв'язок інформації таких звітів 3 інформацією, наведеною у фінансовій звітності, а також враховує їх місце у системі звітності підприємства.

Представники Глобального договору ООН визначають нефінансову звітність як документально оформлену сукупність даних комерційної організації, що відображає середовище існування компанії, принципи та методи співпраці з групами впливу, результати діяльності компанії в економічній, соціальній та екологічній сфері життя суспільства [5, с. 6].

Підходи науковців до визначення сутності поняття «нефінансова звітність» наведені в таблиці 1.

Таблиця 1

Сутність поняття «нефінансова звітність» в наукових джерелах

\begin{tabular}{|c|c|c|}
\hline $\begin{array}{l}\text { № } \\
\text { 3/ח }\end{array}$ & Автор & Визначення поняття \\
\hline 1 & Безверхий К. & $\begin{array}{l}\text { Нефінансову звітність можна визначити як складову інтегрованої } \\
\text { звітності підприємства, яка використовується бізнесом як інстру- } \\
\text { мент відповідальності перед суспільством, а також забезпечує інфо- } \\
\text { рмаційні потреби зацікавлених користувачів такої звітності щодо } \\
\text { економічних, соціальних та екологічних показників, які додатково } \\
\text { розкривають та пояснюють діяльність господарюючого суб’єкта, не } \\
\text { тільки в якісних, але й в кількісних показниках [6, с. } 31]\end{array}$ \\
\hline 2 & Васильчук I. & $\begin{array}{l}\text { Нефінансова звітність містить інформацію як про економічні ре- } \\
\text { зультати діяльності, так і результативність у соціальній та екологіч- } \\
\text { ні сферах }[7, \text { с. } 212]\end{array}$ \\
\hline 3 & $\begin{array}{l}\text { Гордієнко А., } \\
\text { Гнедіна К. }\end{array}$ & $\begin{array}{l}\text { Нефінансова звітність відображає більш повну інформацію щодо } \\
\text { діяльності суб'єкта господарювання, висвітлюючи соціальні та еко- } \\
\text { логічні результати, зокрема, дає можливість ознайомитися із спе- } \\
\text { цифікою діяльності компанії, оцінити вплив ії діяльності на навко- } \\
\text { лишнє природне середовище і суспільство та орієнтована, в цілому, } \\
\text { на майбутнє [8, с. 45] }\end{array}$ \\
\hline
\end{tabular}


Закінчення таблиці 1

\begin{tabular}{|c|l|l|}
\hline $\begin{array}{c}\text { № } \\
\text { 3/п }\end{array}$ & \multicolumn{1}{|c|}{ Автор } & \multicolumn{1}{|c|}{ Визначення поняття } \\
\hline 4 & Король С. & $\begin{array}{l}\text { Нефінансові звіти - всі звіти з соціальної відповідальності бізнесу } \\
\text { [9, с. 104] }\end{array}$ \\
\hline 5 & Москалюк Г. & $\begin{array}{l}\text { Нефінансовий звіт - це дієвий інструмент налагодження діалогу і } \\
\text { взаєморозуміння між підприємством і зовнішнім співтовариством, а } \\
\text { також інструмент його самовдосконалення в частині систем управ- } \\
\text { ління. Нефінансовий звіт - це інструмент прозорості і підзвітності } \\
\text { компанії, що впливає на саму компанію [10, с. 370] }\end{array}$ \\
\hline 6 & Хомуляк Т. & $\begin{array}{l}\text { Нефінансова звітність надає значно більше інформації про вплив } \\
\text { компаніі на суспільство, економіку та навколишнє середовище, } \\
\text { описуючи діяльність компанії у відповідному суспільному контекс- } \\
\text { ті [11, с. 166] }\end{array}$ \\
\hline 7 & $\begin{array}{l}\text { Шигун М., } \\
\text { Давидюк Т. }\end{array}$ & $\begin{array}{l}\text { Нефінансова звітність є інструментом соціальної відповідальності } \\
\text { бізнесу [12, с. 174] }\end{array}$ \\
\hline
\end{tabular}

Джерело: узагальнено авторами

Як видно с табл. 1, переважна більшість науковців зазначають, що нефінансова звітність відображає інформацію стосовно декількох сторін діяльності підприємства (економічної, екологічної та соціальної). Деякі автори визначають іiі як інструмент соціальної відповідальності бізнесу, інші як інструмент налагодження діалогу із зацікавленими користувачами та інструмент вдосконалення підприємства в частині систем управління.

Загалом, нефінансову звітність визначають як звітність, що надає зацікавленим користувачам інформацію стосовно впливу діяльності підприємства на суспільство та навколишне середовище, а також як інструмент соціальної відповідальності бізнесу. Зацікавленими користувачами, в цьому випадку, виступають власники, керівники, фінансові агенти, контрагенти, працівники самого підприємства, органи влади та громадські організації, населення. Їх інформаційні потреби наведені в таблиці 2.
Нефінансові звіти можуть бути представлені користувачам в різних формах:

1. Довільної форми. Такі звіти мають форму буклетів або розміщуються на веб-сторінках підприємств та включають інформацію про соціальні та екологічні програми підприємств. Ця форма звіту $є$ дуже зручною стосовно організації, в той же час, вона не завжди може забезпечити достовірність інформації, поданої у звіті, та надати можливість порівняти дані звіту зі звітами інших підприємств, адже містить вибіркову інформацію.

2. Комплексні звіти, які можуть складатися за одним із наступних методів [14, с. 205-206]:

- комплексний звіт за методом потрійного підсумку;

- комплексний звіт за методом Лондонської групи порівняльного аналізу;

- комплексний звіт за методом групи корпоративного громадянства чи за іншим методом.

3. Стандартизовані звіти - розробляються на підставі вимог і принципів 
міжнародних стандартів. Звіти такої форми дають можливість порівнювати звітність різних підприємств та визна- чити місце конкретного підприємства у міжнародній діловій спільноті.

Таблиця 2

Користувачі нефінансової звітності та їх інформаційні потреби

\begin{tabular}{|c|c|}
\hline $\begin{array}{l}\text { Користувачі не- } \\
\text { фінансової звіт- } \\
\text { ності }\end{array}$ & Інформаційні потреби користувачів \\
\hline $\begin{array}{l}\text { Керівники, влас- } \\
\text { ники (учасники) }\end{array}$ & $\begin{array}{l}\text { Інформація щодо наслідків економічної та соціальної діяльності, ре- } \\
\text { зультати виконання поставлених цілей }\end{array}$ \\
\hline $\begin{array}{l}\text { Фінансові агенти } \\
\text { (кредитори, ін- } \\
\text { вестори) }\end{array}$ & \multirow{2}{*}{$\begin{array}{l}\text { Інформація щодо соціальних і екологічних аспектів діяльності підпри- } \\
\text { ємства у взаємозв'язку } 3 \text { економічними результатами, що дозволить } \\
\text { ефективно оцінити ризики бізнесу }\end{array}$} \\
\hline Партнери & \\
\hline $\begin{array}{l}\text { Працівники під- } \\
\text { приємства }\end{array}$ & $\begin{array}{l}\text { Роз'яснення соціальної ролі їх роботи; надання гарантій зайнятості, } \\
\text { безпеки та охорони здоров'я }\end{array}$ \\
\hline Органи влади & \multirow{3}{*}{$\begin{array}{l}\text { Визначення ролі та оцінка впливу діяльності підприємства на суспільс- } \\
\text { тво: вплив на зовнішнє середовище, кількість створених робочих місць, } \\
\text { інвестиції у розвиток регіону тощо }\end{array}$} \\
\hline $\begin{array}{l}\text { Громадські ор- } \\
\text { ганізації }\end{array}$ & \\
\hline Населення & \\
\hline
\end{tabular}

Найбільш поширеними міжнародними стандартами звітності в галузі соціальної відповідальності бізнесу є: стандарти GRI (The Global Reporting Initiative); стандарти Саншайн із надання корпоративних звітів для зацікавлених сторін; стандарт АА1000; стандарти серії ISO 14000; стандарт ISO 26000; стандарт SA 8000.

3 метою визначення особливостей фінансових та нефінансових звітів необхідно провести їх порівняння (таблиця 3).

Таким чином, можна зробити висновки, що:

- фінансова та нефінансова звітність призначена для однакових груп користувачів інформації, проте інформація нефінансового звіту здатна задовольнити потреби користувачів, які не мають підготовки для розуміння даних фінансової звітності;
- інформація у нефінансовому звіті не повторює, а доповнює інформацію із фінансової звітності;

- поєднавши дані фінансової та нефінансової звітності, можна надати користувачам достатньо інформації про соціально-економічну та екологічну діяльність підприємства.

Саме ідея поєднання фінансових i нефінансових показників у єдиному звіті, стала однією з передумов виникнення концепції інтегрованої звітносTi.

Перехід до складання інтегрованої звітності передбачає відмову від окремого оприлюднення нефінансової звітності, адже існують суттєві недоліки її складання, а саме: недостатня довіра зацікавлених користувачів та складнощі в забезпеченні іiі своєчасності та актуальності. 
Таблиця 3

Порівняльна характеристика фінансової та нефінансової звітності

\begin{tabular}{|c|c|c|}
\hline $\begin{array}{l}\text { Характеристика } \\
\text { звітності }\end{array}$ & Фінансова звітність & Нефінансова звітність \\
\hline Мета складання & $\begin{array}{l}\text { Надання інформації про фінансо- } \\
\text { вий стан підприємства, фінансові } \\
\text { результати діяльності }\end{array}$ & $\begin{array}{l}\text { Відображення інформації про дія- } \\
\text { льність та їі результати у соціальній } \\
\text { сфері, вплив діяльності на екологію } \\
\text { тощо }\end{array}$ \\
\hline Горизонт & $\begin{array}{l}\text { Відображає ретроспективу і по- } \\
\text { точний стан }\end{array}$ & $\begin{array}{l}\text { Відображає поточний стан та цілі на } \\
\text { майбутнє }\end{array}$ \\
\hline Користувачі & \multicolumn{2}{|c|}{ Внутрішні та зовнішні } \\
\hline Періодичність & Щоквартальна, річна & Раз на рік або на два роки \\
\hline $\begin{array}{l}\text { Форми предста- } \\
\text { влення }\end{array}$ & Стандартизована форма & $\begin{array}{l}\text { Довільна форма; комплексні звіти; } \\
\text { стандартизовані звіти }\end{array}$ \\
\hline $\begin{array}{l}\text { Відповідний } \\
\text { стандарт }\end{array}$ & $\begin{array}{l}\text { Міжнародні стандарти фінансо- } \\
\text { вої звітності; НП(С)БО } 1 \text { «Зага- } \\
\text { льні вимоги до фінансової звіт- } \\
\text { ності»; НП(С)БО } 2 \text { «Консолідо- } \\
\text { вана фінансова звітність» }\end{array}$ & $\begin{array}{l}\text { Міжнародні стандарти: } \\
\text { стандарти GRI; AA1000; ISO 26000; } \\
\text { SA8000; ISO 14000; стандарти } \\
\text { Саншайн }\end{array}$ \\
\hline Форми звітності & $\begin{array}{l}\text { Комплексна звітність: } \\
\text { - Баланс } \\
\text { - Звіт про фінансові результати } \\
\text { - Звіт про рух грошових коштів } \\
\text { - Звіт про власний капітал } \\
\text { - Примітки до річної фінансової } \\
\text { звітності }\end{array}$ & $\begin{array}{l}\text { - Звіт про корпоративну соціальну } \\
\text { відповідальність } \\
\text { - Звіт зі сталого розвитку } \\
\text { - Звіт з прогресу } \\
\text { - Звіт за GRI стандартом } \\
\text { - Звіт за стандартом AA1000 та ін. }\end{array}$ \\
\hline
\end{tabular}

Джерело: узагальнено на основі джерел [1, с. 150; 9, с. 109-110]

Причинами цього $\epsilon$ те, що нефінансовій звітності бракує суворих стандартів вимірювання та звітності, які існують стосовно фінансової інформації, а також інформація, наведена в ній, не представлена в контексті бізнес-моделі і стратегії підприємства. Для інвесторів це ускладнює розуміння того, як продуктивність соціальної та екологічної діяльності впливає на фінансову діяльність, і як проблеми сталого розвитку впливають на вартість компанії $[15$, с. 5].

Для глибшого розуміння сутності інтегрованої звітності, доцільно звернутись до визначення, яке наводить Міжнародна рада 3 інтегрованої звітності (IIRC) у Міжнародному стандарті інтегрованої звітності, а саме: «Інтегрований звіт являє собою коротке відображення того, як стратегія, управ- ління, результати та перспективи підприємства в контексті зовнішнього середовища призводять до створення вартості в короткостроковій, середньостроковій та довгостроковій перспективі» [16].

Погляди науковців стосовно сутності інтегрованої звітності мають певні розбіжності (табл.4). Частина науковців розглядає інтегрований звіт як поєднання фінансових та нефінансових показників, тобто узагальнення інформації про фінансовий стан та результати фінансового-господарської, соціальної та екологічної діяльності підприємства в одному звіті. Досить розповсюдженою $є$ інтерпретація економічної сутності інтегрованої звітності як такої, що розкриває питання, які впливають на оцінку здатності підприємства створювати вартість протя- 
гом періоду діяльності. Також варто погодитись із вченими, які розглядають інтегровану звітність як таку, що сформована на принципах стійкого розвитку та надає інформацію про стратегічний напрям розвитку підприємства. Деякі автори розглядають ін- тегровану звітність як інструмент самовдосконалення компанії в частині системи управління та обліку, а також інструмент, що дозволяє оцінити ефективність прийняття управлінських рішень.

Таблиця 4

Поняття «інтегрована звітність» у наукових джерелах

\begin{tabular}{|c|c|c|}
\hline $\begin{array}{l}\text { № } \\
\text { 3/ח }\end{array}$ & Автор & Визначення \\
\hline 1 & $\begin{array}{l}\text { Балашова } \\
\text { Н., Меліхов } \\
\text { В. }\end{array}$ & $\begin{array}{l}\text { Інтегрований звіт передбачає розкриття інформації з питань, які здійс- } \\
\text { нюють суттєвий вплив на оцінку здатності підприємства створювати } \\
\text { вартість в короткостроковому, середньостроковому та довгостроково- } \\
\text { му періодах }[17, \text { с. } 101] \text {. }\end{array}$ \\
\hline 2 & Безве & $\begin{array}{l}\text { Інтегрована звітність - це звітність, що включає як сукупність фінансо- } \\
\text { вих показників, які входять до складу фінансової звітності, так і розра- } \\
\text { хункові фінансові показники, які не входять до такої звітності, а також } \\
\text { нефінансові показники, які надаються на запит бухгалтерської служби } \\
\text { іншими структурними підрозділами підприємства }[18, \text { с. } 54] \text {. }\end{array}$ \\
\hline 3 & Єршс & $\begin{array}{l}\text { Інтегрований звіт - це дієвий інструмент налагодження діалогу і взає- } \\
\text { морозуміння між компаніями і зовнішнім співтовариством, а також } \\
\text { інструмент самовдосконалення компанії в частині системи управління } \\
\text { та обліку }[19, \text { с. } 457] \text {. }\end{array}$ \\
\hline 4 & Кост & $\begin{array}{l}\text { Інтегрована звітність } є \text { новим напрямом розвитку корпоративної звіт- } \\
\text { ності, що ставить своєю метою надання різноманітним стейкхолдерам } \\
\text { інформації про ключові чинники створення вартості компанією. У інте- } \\
\text { грованій звітності компанії надається комплексний огляд стратегії, сис- } \\
\text { теми управління, ефективності компанії, існуючих можливостей, перс- } \\
\text { пектив і ризиків та їх впливу на генерування вартості впродовж трива- } \\
\text { лого періоду [20, с. } 53] \text {. }\end{array}$ \\
\hline 5 & Лох: & $\begin{array}{l}\text { Інтегрована звітність як продукт цілісної обліково-аналітичної системи } \\
\text { містить в собі коло фінансових і не фінансових показників, які мають } \\
\text { бути тісно взаємозв'язані і наведені з позицій обгрунтування власної } \\
\text { стратегії діяльності компанії }[21, \text { с. } 56] \text {. }\end{array}$ \\
\hline 6 & $\begin{array}{l}\text { Николишин } \\
\text { А. }\end{array}$ & $\begin{array}{l}\text { Інтегрована звітність - найбільш інноваційний і цілісний підхід до кор- } \\
\text { поративної звітності у світі, метою якого є надання максимально якіс- } \\
\text { ної, повної інформації постачальникам фінансового капіталу, яким ва- } \\
\text { жлива оцінка здатності підприємства створювати вартість протягом } \\
\text { тривалого часу [22, с. 55]. }\end{array}$ \\
\hline 7 & $\begin{array}{l}\text { Проданчук } \\
\text { М. }\end{array}$ & $\begin{array}{l}\text { Інтегрована (корпоративна) звітність - гармонізація фінансової та не- } \\
\text { фінансової звітності, де узагальнено інформацію про фінансовий стан } \\
\text { та результати фінансово-господарської, соціальної та екологічної дія- } \\
\text { льності підприємств, що дає можливість оцінити ефективність прийня- } \\
\text { тих управлінських рішень та визначити стратегічні аспекти розвитку } \\
\text { [23, с. } 25] \text {. }\end{array}$ \\
\hline
\end{tabular}

Джерело: узагальнено авторами 
Розглянувши різні підходи вчених, можна визначити інтегровану звітність як сукупність фінансових та нефінансових показників, які надають зацікавленим користувачам уявлення про стратегічний напрям розвитку підприємства, а також про те, як створюється його вартість, шляхом розкриття інформації про економічні, соціальні та екологічні аспекти його діяльності.

Виходячи 3 наведених науковцями визначень інтегрованої звітності, можна сформулювати мету іï складання, що полягає у наданні інформації зацікавленим користувачам стосовно оцінки здатності підприємства створювати вартість протягом тривалого часу, а також залученні додаткового капіталу від інвесторів.

В міжнародних корпораціях складання інтегрованої звітності регулюється міжнародними стандартами звітності, зокрема, Міжнародним стандартом інтегрованої звітності (The International <IR> Framework), ціллю якого $\epsilon$ встановлення провідних принципів i елементів змісту, які визначають загальний зміст інтегрованого звіту. Стандарт також визначає інформацію, яку потрібно включити до інтегрованого звіту, з метою оцінки здатності підприємства створювати вартість.

Деякі спроби регулювання інтегрованої звітності з'являються і в Україні. Так, статтею 1 та статтею 11 Закону України «Про бухгалтерський облік та фінансову звітність в Україні» [24], а також Порядком подання фінансової звітності, затвердженим постановою Кабінету Міністрів України від 28 лютого 2000 р. № 419 [25], введено Звіт про управління. Наказом Міністерства фінансів України № 982 від 07.12.2018 року розроблено Методичні рекомендації зі складання Звіту про управління [26], відповідно до яких Звіт про управління має містити достовірну фінансову та нефінансову інформацію про діяльність підприємства, його стан та перспективи розвитку та розкривати основні ризики і невизначеності його діяльності.

Інтегрована звітність, що містить фінансові та нефінансові показники, має сильні та слабкі сторони, які можна порівняти 3 перевагами та недоліками фінансової та нефінансової звітності, провівши SWOT-аналіз. Peзультати такого порівняння узагальнено в таблиці 5.

Таблиця 5

SWOT-аналіз фінансової, нефінансової та інтегрованої звітності

\begin{tabular}{|c|c|c|c|}
\hline & Фінансова звітність & Нефінансова звітність & Інтегрована звітність \\
\hline $\begin{array}{l}\text { Сильні сто- } \\
\text { рони }\end{array}$ & $\begin{array}{l}\text { - законодавчо закріп- } \\
\text { лений порядок форму- } \\
\text { вання фінансової звіт- } \\
\text { ності; } \\
\text { - своєчасність скла- } \\
\text { дання та подання. }\end{array}$ & $\begin{array}{l}\text { - надає значно більше } \\
\text { інформації про вплив } \\
\text { компанії на суспільст- } \\
\text { во, економіку та навко- } \\
\text { лишнє середовище, } \\
\text { описуючи діяльність } \\
\text { компанії у відповідно- } \\
\text { му суспільному кон- } \\
\text { тексті. }\end{array}$ & $\begin{array}{l}\text { - комплексне розкриття } \\
\text { фінансових, економі- } \\
\text { них, соціальних та еко- } \\
\text { логічних показників. }\end{array}$ \\
\hline
\end{tabular}


Закінчення таблиці 5

\begin{tabular}{|c|c|c|c|}
\hline & Фінансова звітність & Нефінансова звітність & Інтегрована звітність \\
\hline $\begin{array}{l}\text { Слабкі сто- } \\
\text { рони }\end{array}$ & $\begin{array}{l}\text { - надає інформацію } \\
\text { лише про фінансове } \\
\text { становище підприємс- } \\
\text { тва та фінансові ре- } \\
\text { зультати його діяльно- } \\
\text { сті. }\end{array}$ & $\begin{array}{l}\text { - ресурсозатратність; } \\
\text { - неможливість засто- } \\
\text { сування для аналізу } \\
\text { процесу створення дов- } \\
\text { гострокової вартості } \\
\text { підприємства; } \\
\text { - несвоєчасна публіка- } \\
\text { ція. }\end{array}$ & $\begin{array}{l}\text { - відсутність розробленої } \\
\text { методики формування } \\
\text { інтегрованого звіту; } \\
\text { - складність при визна- } \\
\text { ченні того, яка саме ін- } \\
\text { формація буде корисною } \\
\text { та суттєвою. }\end{array}$ \\
\hline Мож & $\begin{array}{l}\text { - забезпечення } \\
\text { інформаційної ланки } \\
\text { між підприємством і } \\
\text { суспільством. }\end{array}$ & $\begin{array}{l}\text { - полегшення доступу } \\
\text { до фінансових ресурсів; } \\
\text { - допомога у розбудові } \\
\text { процесу управління } \\
\text { СВБ; } \\
\text { - підвищення готовнос- } \\
\text { ті підприємства працю- } \\
\text { вати на інших ринках; } \\
\text { - зміцнення ділових } \\
\text { відносин. }\end{array}$ & $\begin{array}{l}\text { - поліпшення відносин } 3 \\
\text { інвесторами та іншими } \\
\text { зацікавленими особами; } \\
\text { - збільшення прозорості } \\
\text { та достовірності даних; } \\
\text { - залучення додаткового } \\
\text { капіталу від інвесторів; } \\
\text { - контроль і управління } \\
\text { ризиками підприємства, } \\
\text { ефективністю викорис- } \\
\text { тання ресурсів. }\end{array}$ \\
\hline 3aг & $\begin{array}{l}\text { - сувора } \\
\text { регламентація обсягів } \\
\text { та рівня деталізації } \\
\text { даних не дозволяє по- } \\
\text { вно розкрити інфор- } \\
\text { мацію необхідну ко- } \\
\text { ристувачам. }\end{array}$ & $\begin{array}{l}\text { - можлива критика; } \\
\text { - розкриття в звіті ін- } \\
\text { формації, яка може бу- } \\
\text { ти конфіденційною. }\end{array}$ & $\begin{array}{l}\text { - розкриття в звіті інфо- } \\
\text { рмації, яка може бути } \\
\text { конфіденційною. }\end{array}$ \\
\hline
\end{tabular}

Джерело: складено авторами

Таким чином, інтегрована звітність, на відміну від фінансової та нефінансової звітності, синергетично розкриває фінансові, економічні, соціальні та екологічні показники, що дає змогу визначити стратегічний напрям розвитку підприємства та механізм створення його вартості, що, в свою чергу, позитивно впливає на взаємовідносини $з$ інвесторами та іншими зацікавленими сторонами та надає підприємству деякі переваги.

Висновки. 1. Неспроможність фінансової звітності задовольнити потреби користувачів у інформації, що стосується соціальної та екологічної сфер діяльності підприємства, стало однією з причин появи концепції нефінансової звітності, яка надає інформацію саме про вплив підприємства на суспільство, економіку та навколишне середовище, описуючи його діяльність у відповідному суспільному контексті. Проте, головним недоліком окремого оприлюднення нефінансової звітності $\epsilon$ неможливість іiі застосування для аналізу процесу створення довгострокової вартості підприємства.

2. Поєднання даних фінансової та нефінансової звітності дає можливість надати користувачам достатньо інформації про соціально-економічну та екологічну діяльність підприємства, що стало однією $з$ передумов виник- 
нення концепції інтегрованої звітносTi.

3. Інтегрована звітність комплексно розкриває інформацію щодо ефективності використання підприємством різних видів капіталів або впливу на них, можливостей підприємства створювати вартість, синергетично відображає інформацію про стратегію його розвитку на коротко-, середньо- та довгостроковий періоди, є джерелом повної інформації для прийняття рішень користувачами звітності, а також дає можливість здійснювати контроль та управління ризиками й ефективністю використання ресурсів.

4. Формування в Україні з 2019 року Звіту про управління є проявом загальноєвропейської та світової тенденції до складання великими підприємствами інтегрованої звітності, де фінансова звітність - це лише одна 3 складових частин звіту, а головним завданням $\epsilon$ всебічне представлення діяльності підприємства.

\section{Список використаної літератури}

1. Корягін М. В., Куцик П. О. Проблеми та перспективи розвитку бухгалтерської звітності: монографія. Київ : Інтерсервіс. 2016. 276 с.

2. Ляхович Г. І., Заяць М.Я. Концепція інтегрованої звітності: історичні аспекти виникнення та проблеми впровадження. Науковий вісник Херсонського державного університету. Сер. : Економічні науки. 2016. Вип. 16(2). С. 141-146.

3. Домарадзька Г. С., Фурман М.Б. Реалізація «концепції сталого розвитку» в Україні, як передумова ефективної інтеграції в світову економіку. Вісник Національного університету «Львівська політехніка». Менеджмент та підприємництво в Україні: етапи становлення і проблеми розвитку. 2012. № 748. С. 350356.

4. Комарова К. В., Ковальчук Н. В. Соціальна відповідальність як складова стратегії розвитку бізнесу на підприємствах України. Інноваційна економіка. 2016. № 5-6. С. 25-30.

5. Воробей В., Журовська I. Нефінансова звітність: інструмент соціально відповідального бізнесу. К.. 2010. 84 c. URL: http://www.svb.org.ua/publications. 6. Безверхий К. В. Економічна сутність поняття «нефінансова звітність». Науковий вісник Національної академії статистики, обліку та аудиту. 2017. № 1-2. С. 23-34. 
7. Васильчук I. П. Нефінансова звітність як інструмент управління сталим розвитком корпорацій. Науковий вісник Міжнародного гуманітарного університету. Серія : Економіка і менеджмент. 2015. Вип. 11. С. 212-215.

8. Гордієнко А. М., Гнедіна К.В. Інтегрована звітність як інструмент забезпечення сталого розвитку суб'єктів господарювання. Юність науки 2015: соціально-економічні та гуманітарні аспекти розвитку суспільства: збірник тез доповідей Міжнародної студентської науково-практичної конференції (м. Чернігів 2324 квітня 2015 р.): у 9 ч.. Чернігів: ЧНТУ, 2015. Ч. 4. С. 45-47.

9. Король С. Нефінансова звітність підприємства. Вісник Київського національного торговельно-економічного університету. 2011. № 6. С. 102-113.

10. Москалюк Г. О. Нефінансова звітність у реалізації концепції сталого розвитку в Україні. Облік і контроль в управлінні економічною стійкістю підприємств в умовах глобалізації: монографія / під ред. В. Ф. Максімової. Одеса: OHEУ. 2014. C. 323-373.

11. Хомуляк Т. І. Потреба в інтегрованій звітності як у новому форматі звітності для бізнесу. Фінансово-кредитна діяльність: проблеми теорії та практики. 2015. Вип. 1. С. 65-172.

12. Шигун М. М., Давидюк Т.В. Корпоративна соціальна звітність як перспектива інформування про людський капітал вітчизняних компаній. Вісник Запорізького національного університету : Економічні науки : зб. наук. пр. Запоріжжя : ЗНУ, 2011. № 1 (9). С. 173-178.

13. Герасименко О. Соціальний облік та нефінансова звітність як інструменти реалізації соціальної відповідальності. Вісник Київського національного університету імені Тараса Шевченка. Економіка. 2012. Вип. 137. С. 39-42.

14. Проданчук М. А. Нефінансова звітність - ефективний інструмент в реалізації управлінських рішень. Збірник наукових праць Таврійського державного агротехнологічного університету (економічні науки). 2013. № 2(2). С. 202-214.

15. Eccles R. G., George S. Corporate and Integrated Reporting: A Functional Perspective. Harvard Business School Working Paper. 2014. No. 14-094. P. 1-21.
16.
Международный
стандарт
$<$ ИО $>$.
URL:

http://ir.org.ru/attachments/article/108/13-12-08-THE-INTERNATIONAL-IRFRAMEWORK.docx_en-US_ru-RU.pdf. 
17. Балашова Н. Н., Мелихов Н.Н. Организационно-методические подходы к разработке учетной политики для целей формирования когерентноинтегрированной отчетности агропромышленных холдингов. Бизнес. Образование. Право. Вестник Волгоградского института бизнеса. 2014. № 2 (27). С. 99104.

18. Безверхий К. В. Інтегрована звітність підприємства: економічна сутність поняття. Науковий вісник Національної академії статистики, обліку та аудиту: зб. наук. праць. 2016. №4. С. 43-58.

19. Єршова Н. Ю. Розвиток методологічних основ формування інтегрованої звітності. Науковий вісник Ужгородського університету. Серія : Економіка. 2016. Вип. 1(1). С. 451-459.

20. Костирко Р. О. Інтегрована звітність - інструмент соціально відповідального бізнесу.Часопис економічних реформ. 2014. № 1. С. 49-54.

21. Лоханова Н. О. Інтегрована звітність як продукт цілісної обліковоаналітичної система. Вісник соціально-економічних досліджень : зб. наук. пр. / голов. ред. М. І. Звєряков; Одеський нац. екон. ун-т. - Одеса. 2012. Вип. 47 (4). С. 50-56.

22. Николишин А. С. Теоретичні основи формування інтегрованої звітності підприємства. Тези XII Всеукр. наук. on-line конф. студентів, магістрів та аспірантів 3 міжнар. Участю: Сучасні проблеми екології»(17 травня 2016). Житомир: ЖДТУ. 2016. С. 55-56.

23. Проданчук М. Інтегрована звітність - інструмент управління підприємством. Бухгалтерський облік і аудит. 2014. № 2. С. 24-31.

24. Закон України «Про бухгалтерський облік та фінансову звітність в Україні» № 996, редакція від 16.11.2018. URL: https://zakon.rada.gov.ua/laws/show/996-14. 25. Порядок подання фінансової звітності, затверджений постановою Кабінету Міністрів України від 28 лютого 2000 p. № 419 . URL: https://zakon.rada.gov.ua/laws/show/419-2000-\%D0\%BF.

26. Методичні рекомендації зі складання звіту про управління, затверджені Наказом Міністерства фінансів України № 982 від 07.12.2018. URL: http://zakon.rada.gov.ua/rada/show/v0982201-18. 